\title{
THE EFFECT OF COOPERATIVE LEARNING MODELS OF INVESTIGATION GROUP TYPE ON SCIENTIFIC ATTITUDES
}

\author{
${ }^{1}$ Ganesha University Of Education, Singaraja, Indonesia \\ ${ }^{2}$ Ganesha University of Education, Singaraja, Indonesia \\ ${ }^{3}$ Ganesha University of Education, Singaraja, Indonesia
}

Anggita Putri, N.K ${ }^{1}$, Citra Wibawa, I. $M^{2}$, Widiana. I.W ${ }^{3}$

\author{
A R T I C L EI N F O \\ Article history: \\ Received 19 April 2016 \\ Received in revised form \\ 6 October 2016 \\ Accepted 12 October 2016 \\ Available online 20 October \\ 2016
}

Keywords: group investigation, scientific attitude

\begin{abstract}
A B S T R A C T
The aim of this study is to find out the significant differences of scientific attitude between a group of students who is taught by cooperative learning in type of group investigation and a group of students who is taught by conventional learning. This study is quasi experiment with nonequivalent control group design and post test only design. The population of this study is the whole V grade students Gugus I in Buleleng Sub-district which is involving 149 students. The sample is taken randomly by using random sampling. The sample is 60 students from $\mathrm{V}$ grade students of SDN 3 Banyuning and SDN 2 Banyuning. Validation on scientific attitude instrument of content validity with Greogory test, grain validity using product moment and reliability with Alpha Cronbach.The data is taken by using questionnaire and analyze using descriptive statistics and inferential statistics analysis (T-test) with polled variant formula. The finding shows that the average score of post test group is 83,71 which belong to high category. Meanwhile, the average score of conventional group is 68,47 which belong to moderate category. The obtain result of $\mathrm{T}$ test is $\mathrm{t}_{\text {count }}=9,99$ belong to $5 \%$ significant from table $=2,000$. In conclusion, $\mathrm{t}_{\text {count }}>\mathrm{t}_{\text {table, }}$ with a result that $\mathrm{H}_{0}$ is rejected and $\mathrm{H}_{1}$ is accepted.It means that there was a significant difference in scientific attitudes between classes that were taught by cooperative learning model of group investigation type and classes that were taught by conventional learning model. Thus, cooperative learning model of group investigation type had a positive effect on students' scientific attitude.
\end{abstract}




\section{Introduction}

Natural Sciences (IPA) is one of the main subjects in the Indonesian education curriculum, including at the elementary school level. Natural science in everyday life is needed to solve an identifiable problem. Susanto (2013: 167) states that, "IPA is a human effort in fulfilling the universe through observation, using procedures, and explained by reason so as to get a conclusion". That means to understand the universe requires an appropriate observation and using procedures, so that students are very active in learning science so that they can draw conclusions based on the problems they find.

The objective of science learning in elementary school relates to how to find out systematically so that science is not only mastery of a collection of knowledge in the form of concepts, facts, and principles, but also a process of discovery accompanied by the development of scientific attitudes. Bundu (2006: 11) states, broadly speaking "IPA has three components, namely as a product, process, and scientific attitude". IPA as a product is a collection of empirical activities and analytic activities carried out by scientists for centuries. Science as a process is how to gather facts and how to connect facts to interpret them. While science as a scientific attitude is an attitude that scientists have in seeking and developing knowledge through scientific activities.

During this time the process of learning science in elementary school only focused on cognitive and psychomotor. A scientific attitude as one of the learning outcomes in the affective domain is rarely developed. Purwanti (2015) states that science learning in general is only product oriented in elementary schools, while students' scientific processes and attitudes to achieving these products are less noticed. Even though the attitude of students in learning can also be an interpretation of students in participating in learning activities. Students' scientific attitude is one component of the attitude that must be developed at the elementary school level, especially in science subjects. Thus, the development of scientific attitudes in science learning cannot be separated. As we know scientific attitude has its own role in motivating students to be active in science learning, because by having a scientific attitude, students will be encouraged to dig further to answer the curiosity students have.

In a learning activity, students 'positive attitudes are needed to encourage students' abilities to achieve learning goals. The positive attitude of students in learning activities about something that is not yet known can encourage students to learn to find out. The positive attitude in question is a very important attitude possessed by students inside and outside science learning including attitudes of curiosity, open-mindedness, critical thinking, and respect for data (Septiari, 2013). With the existence of a scientific attitude, students take a stand along with their interest in an object. Students have beliefs and convictions about what should be done.

But in fact, from the four scientific attitudes, it seems that the planting of scientific attitudes in students in science learning at the elementary level, especially in SD Gugus I, BulelengSubdistrict, is not optimal. This was reinforced based on the results of observations during science learning on 28-30 November 2017 class V in Cluster I of BulelengSubdistrict by giving a questionnaire to students to know a definite description of students' initial scientific attitude. It is known that the scientific attitude of students in Cluster I of BulelengSubdistrict tends to be low.

After further interviews the causes of students' low scientific attitudes are (1) the science learning process in the classroom is still teacher-centered (teacher center), (2) in the learning process the teacher tends to use the lecture method, question and answer, and assignments, (3) when teaching teachers rarely use learning media, (4) practicum activities on science subjects are rarely carried out due to time constraints, (5) difficulties experienced by teachers in fostering students' interest in learning so students are active in the learning process.

Based on the problems encountered in SD Gugus I Sub-District Buleleng, it is necessary to repair and renew the learning process. One of the factors that can influence the success of the learning process is the teacher. A professional teacher must be able to identify the needs of his students. In addition to speeding up student understanding, teachers should provide hands-on experience to students to find concepts from the subject matter they are learning. So that in the learning process students will feel learning is more meaningful (Suputra, 2013). One alternative in improving learning in accordance with these problems is to use a cooperative learning model type group investigation.

Dewi (2017) states, the investigation group learning model is a form of cooperative learning model that has a press point on the participation and activities of students to search for their own material or everything about the subject matter to be studied. This learning model combines the principles of democratic learning, which means more emphasis on the activeness of students in the learning process, both from the initial stage and the final stages of learning, including also in which students will be free to choose the material according to the topic that will be discussed during the learning process. By applying cooperative learning model group investigation type can train students to develop student competencies 
both in terms of cognitive in the form of knowledge and understanding, affective in the form of values and attitudes obtained in collaborating with group members, and psychomotor in the form of skills and activeness in the process learning.

In applying the investigation group learning model consists of six stages, namely: identifying topics and arranging students into groups, planning tasks to be studied, carrying out investigations, preparing reports, presenting final reports, and evaluating (Slavin, 2010).

Science learning with cooperative learning models group investigation type indirectly also able to develop psychomotor and affective students. The difference between the above studies and the research that will be carried out is located in the application of the investigation group learning model to develop the scientific attitude of students in Cluster I of Buleleng District. The advantages of the group investigation learning model are as follows. (1) Investigation group learning model has a positive impact on improving student learning achievement, (2) The application of this model has a positive effect, which can increase student learning motivation, (3) Learning is done to create an atmosphere of mutual cooperation and interaction between students in groups without looking at the background, (4) This model also trains students to choose good abilities in communicating and using their opinions, (5) Motivating and encouraging students to be active in the learning process from the first stage to the final stage of learning.

Based on these problems, a study was conducted to determine the effect of group investigation learning model on the scientific attitude of students in elementary school by conducting a study entitled "the influence of cooperative learning type group investigation on the scientific attitude of class V students in semester II in Cluster I Buleleng Sub-district 20172018 ".

This study aims to find out the significant differences in scientific attitudes between groups of students who are taught using cooperative learning models group investigation with groups of students who are taught using conventional learning models in fifth grade elementary school students in Cluster I Buleleng District 2017/2018 school year. Learning outcomes, especially scientific attitudes with the cooperative learning type Goup investigation model have a positive impact on students, teachers, and principals.

\section{Methods}

This research is an experimental research. This research is categorized as quasi experimental research because not all variables appear and experimental conditions can be tightly regulated and controlled. This study followed a quasi-experimental research design with non-equivalent post-test only control group design. The implementation of this study consists of three stages, namely, (1) the preparation stage, (2) the implementation stage, (3) the final stage (the final stage of the experiment).

Population is the entire object used in a study. In this study the population is all students in class $\mathrm{V}$ of Cluster I District of Buleleng with many students 149 people. Before determining the sample, the equality test is done first by analyzing the initial scientific attitude value using the ANAVA formula A. Based on the results of the analysis, the result of Fcount is 0.72 and the value of Ftable in dbantar 4 and dbdalam 144 is 2.45. Thus Fcount $<$ Ftable, then $\mathrm{HO}$ is accepted and $\mathrm{Ha}$ is rejected. So there is no significant difference in the scientific attitude of class $\mathrm{V}$ students in Cluster I of BulelengSubdistrict. This means that each member of the population, namely all students in grade $\mathrm{V}$ elementary school in Cluster I of BulelengSubdistrict, are equal or homogeneous. After knowing the five schools are equal, sample selection is conducted. The sample is part of the entire population that will be used as research. In determining the sample the technique used is random sampling. Based on the results of random sampling, it was found that the experimental group selected was class V SD N 3 Banyuning which amounted to 28 students. While the chosen control group was class V SD N 2 Banyuning which amounted to 32 students.

The data collected in this study is the scientific attitude data of students with non-test methods. The instrument used in this study is the scientific attitude questionnaire which amounts to 25 items. To find out the quality of its contents, the content validity test (expert test) is conducted first by two experts to get a good quality questionnaire. The two experts in this matter are two PGSD lecturers at UniversitasPendidikanGanesha. The first expert judges were I GedeMargunayasa, S.Pd.,M.Pd, a specialist in Natural Sciences Education and the second expert judges Dr. I WayanWidiana, S.Pd., M.Pd. Specialist in Educational Research and Evaluation. The validity of the items using the product moment formula and reliability using the Cronbach Alpha formula. The criteria used as guidelines for the validity of the contents of the scientific attitude questionnaire are in Table 01. 
Table 01 Validity Criteria for the Content of the Scientific Attitude Questionnaire

\begin{tabular}{ll}
\hline Skor & Validasi \\
$0,80-1,00$ & Very High \\
$0,60-0,79$ & High \\
$0,40-0,59$ & Average \\
$0,20-0,39$ & Low \\
$0,00-0,19$ & Very Low \\
\hline
\end{tabular}

The data obtained were analyzed using descriptive analysis and inferential statistics, namely the $t$ test. Descriptive statistical analysis was used to calculate the mean, median, mode, standard deviation, and variance in the experimental class and the control class. While the inferential analysis method used is the t-test. However, before counting using the t-test, the prerequisite test is first, namely normality and homogeneity of variance. In this study the t-test formula used was polled variance.

\section{Findings and Discussion}

Based on the results of data analysis with descriptive statistical analysis in the experimental and control classes the following results were obtained. The description of scientific attitude data will describe the mean, median, mode, standard deviation, variance, maximum score, minimum score, and range of data. The descriptions in the two groups are presented in Table 02.

Table 02.

Recapitulation of Results of Scientific Attitude Score Calculation

\begin{tabular}{ccc}
\hline Statistical & \multicolumn{3}{c}{ Scientific attitude } \\
Data & Group & Group \\
& Experiment & Control \\
Mean & 83,71 & 68,47 \\
Median & 84,39 & 67,10 \\
Modus & 85,50 & 65,18 \\
Standard & 5,97 & 5,84 \\
Deviation & & \\
\hline
\end{tabular}

Based on Table 2 the scientific attitude of the experimental group was 83.71, the median was 84.39, the mode was 85.50 , the variance was 35.62 , and the standard deviation was 5.97 . The average score of the scientific attitude of the experimental group students is 83.71 (located in the range 84-87) with a frequency of 9 . The average score of the scientific attitude of the experimental group (taught by the group investigation learning model) is 83.71. If the average scientific attitude of the experimental group is converted into a Five-Scale Benchmark Reference (PAP) at a very high category.

Whereas in the mean control class the scientific attitude of the control group was 68.47 median at 67.10 mode based on 65.18 variance of 34.06 and the standard deviation of 5.84. The average score of the scientific attitude of the control group is 68.47 in the interval 68-71 with frequency 4 . The average score of the scientific attitude of the control group (learned by conventional learning models) is 68.47. If the average scientific attitude of the control group is converted into the Five-Scale Benchmark Reference (PAP) at the medium category.

Before conducting a hypothesis test, a prerequisite analysis test is carried out, namely the normality test and homogeneity test. A summary of the results of the normality tests of the experimental and control classes can be seen in Table 3 .

Table 3. Summary of the Normality Test Results of Scientific Attitude Data Distribution

\begin{tabular}{ccccc}
\hline \multirow{2}{*}{$\mathrm{N}^{\mathrm{N}}$} & $\mathrm{N}$ & $\chi_{\text {count }}^{2}$ & $\chi^{2}$ table & Status \\
\cline { 2 - 5 } & Experiment & 4,28 & 7,815 & Normal \\
2 & Control & 5,22 & 7,815 & Normal \\
\hline
\end{tabular}

Based on the results of calculations using the chi-square formula, the scientific attitude of the experimental group students is 4.28 and with a significance level of $5 \%$ and $\mathrm{db}=3$ is 7.815 . This means, 
the scientific attitude of the experimental group students is smaller than the scientific attitude data of the experimental group students are normally distributed.

Meanwhile, the scientific attitude of the control group students is 5.22 and with a significance level of $5 \%$ and $\mathrm{db}=3$ is 7.815 . This means that the control group post-test results are smaller than 0 so that the scientific attitude data of the control group students are normally distributed.

After calculating the normality of the data then homogeneity will be tested against the variance of pairs between the experimental and control groups. The test used is the F-test with homogeneous data criteria if Fcount<Ftable. A summary of the results of the variance homogeneity test between experimental and control groups is presented in Table 4.

Table 4. Summary of Homogeneity Test Results of Experimental Groups and Control Groups

\begin{tabular}{cccc}
\hline $\begin{array}{c}\text { Scientific Attitude Data Group } \\
\text { Experiment } \\
\text { Control }\end{array}$ & $\mathrm{F}_{\text {count }}$ & $\mathrm{F}_{\text {table }}$ & $\begin{array}{c}\text { Status } \\
\text { Homogene } \\
\text { ous }\end{array}$ \\
\hline
\end{tabular}

Based on the table above, it is known that the scientific attitude of the experimental and control group students is 1.05 . While Ftable with db numerator $=27, \mathrm{db}$ mention $=31$, and a significance level of $5 \%$ is 1.84 . This means that Fcount $<$ Ftable so that the variance of the scientific attitude data of the experimental group and control students is homogeneous.

Based on the data analysis prerequisite test, it was found that the scientific attitude data of the experimental group and control students were normal and homogeneous. After obtaining the results of the data analysis prerequisite test, followed by testing the research hypothesis. Testing the hypothesis is done by using an independent sample (uncorrelated) $t$-test with the polled variance formula with the H0 criterion rejecting if tcount $>\mathrm{t}$ table and $\mathrm{HO}$ accept if tcount $<$ ttable. Summary of hypothesis testing is presented in Table 5 as follows.

Table 5. Summary of Hypothesis Test Results

\begin{tabular}{|c|c|c|c|c|c|c|c|c|c|c|}
\hline \multirow{2}{*}{$\begin{array}{l}\text { Scienti } \\
\text { fic attitude }\end{array}$} & \multirow[t]{2}{*}{$\mathrm{S}^{2}$} & \multirow{2}{*}{\multicolumn{2}{|c|}{ 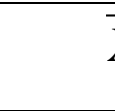 }} & & \multirow{2}{*}{$\mathrm{N}$} & \multirow{2}{*}{\multicolumn{2}{|c|}{$\mathrm{b}$}} & \multirow{2}{*}{$\begin{array}{c}\mathrm{T} \\
\text { count }\end{array}$} & \multirow{2}{*}{ table } & \multirow{2}{*}{ Conclusion } \\
\hline & & & & & & & & & & \\
\hline Experi & 35 & & 8 & & 2 & & & & & \\
\hline ment Group & ,62 & 3,71 & & 8 & & & ! & 9 & 2 & \\
\hline Contro & 34 & & 6 & & $\overline{3}$ & 8 & & ,99 & ,000 & $\mathrm{H}_{0}$ rejected \\
\hline 1 Group & ,06 & 8,47 & & 2 & & & & & & \\
\hline
\end{tabular}

Based on the results of t-test calculations, obtained tcount of 9.99. While $\mathrm{t}$ table with $\mathrm{db}=58$ and a significance level of $5 \%$ is 2,000 . This means that tcount is greater than $t$ table (tcount $>$ ttable) so that $\mathrm{H} 0$ is rejected or $\mathrm{H}\urcorner \mathrm{a}$ is accepted. Thus, it can be interpreted that there are significant differences in scientific attitudes between students who are taught with cooperative learning models investigation group type and students who are taught with conventional learning models in class V in SDN Gugus I District Buleleng in the even semester of the school year 2017/2018. The comparison of the results of the average scientific attitude of the experimental group was 83.71 greater than the average scientific attitude of the control group of 68.47.

After hypothesis testing, the calculated marginal estimated means the student's scientific attitude score. The summary table estimates marginal means scores of scientific attitudes of control and experimental groups are available in Table 6.

Table 6 .Estimated Marginal Means

\begin{tabular}{|c|c|c|c|c|c|}
\hline \multirow{2}{*}{$\begin{array}{l}\text { Depen } \\
\text { dent of } \\
\text { Variables }\end{array}$} & \multirow[t]{2}{*}{ Group } & \multirow[t]{2}{*}{ Mean } & \multirow{2}{*}{$\begin{array}{l}\text { Std. } \\
\text { Eror }\end{array}$} & \multicolumn{2}{|c|}{ 95\% Confidence Interval } \\
\hline & & & & $\begin{array}{l}\text { Lower } \\
\text { Bound }\end{array}$ & $\begin{array}{l}\text { Upper } \\
\text { Bound }\end{array}$ \\
\hline $\begin{array}{l}\text { Scientif } \\
\text { ic attitude }\end{array}$ & $\begin{array}{l}\text { Experim } \\
\text { ent }\end{array}$ & 83,71 & 1,115 & 81,483 & 85,945 \\
\hline & Control & 68,47 & 1,043 & 66,382 & 70,556 \\
\hline
\end{tabular}


Based on the calculation of estimated marginal means using SPPS 17.0, the estimated marginal means of the group of students learning using the group investigation learning model were 83.71 while the control group was 68.47. Comparison of the results of estimated marginal estimation means the scientific attitude of the experimental group is greater than the control group. Thus it means that the group investigation learning model has a positive effect on scientific attitudes.

\section{Discussion}

Based on the results of the t-test analysis, it is known that tcount $=9.99$ and table $=2,000$ at $\mathrm{dk}=$ 58 and the significance level of 5\%. From the results of these calculations, it appears that tcount $>t$ table.

This means that there are significant differences in scientific attitudes between groups of students who are taught by the investigation group learning model and groups of students who are taught using conventional learning models. Hypothesis testing shows that there are differences in scientific attitudes between groups of students who are taught by cooperative learning models investigation group type and groups of students who are taught with conventional learning models. When viewed from the estimated marginal means it was found that the average scientific attitude score of the experimental group students was greater than the control group (83.71> 68.47). That means the scientific attitude of students who are taught by cooperative learning model group investigation type is better than the group of students who are taught with conventional learning models. So the group investigation learning model has a positive effect on students' scientific attitudes.

Significant differences in scientific attitudes between the experimental group and the control group were caused by differences in treatment in the learning process and steps. The development of a scientific attitude will appear in the stages of the group investigation learning model starting from the grouping stage to the evaluating stage. First at the grouping stage is able to develop an open minded attitude. This is evident when the teacher provides topics that will be used as material for discussion and the teacher directs students to form groups of each learning, each student accepts who is a member of the group without distinguishing the background. Organizing students into study groups can provide hands-on experience to train students to discuss with group members and train their abilities to solve problems given by the teacher. This is in accordance with the opinion (Arya, Indrani, Ardana, \& Wiyasa, 2017) that group learning students are able to discuss the topics given by the teacher by exchanging information between friends in one group.

At the stage of investigation, students look more active, easy to work together, responsibility, and always want to try new things in carrying out lab work on the material of the earth and the universe. When students take part in practical activities, students appear active and enthusiastic. This shows that students' curiosity towards the subject matter is already owned by the students themselves. In addition, the attitude of curiosity towards something new also appears from the enthusiasm of students to carry out practical activities that have never been done before if the practicum is done, students continue to try and try until the practicum really works.

In addition to the investigation phase, the organizing stage is effective in developing aspects of respect for data, open-minded attitude, and critical thinking. It appears that at this stage students make reports in accordance with what they get based on the results of the lab without any data manipulation actions. In addition, in making reports students exchange ideas (discussions) with their group friends so that an open minded attitude towards students will appear.

At the presenting stage, being able to develop a critical attitude and an open minded attitude towards the opinions of others. This is evident when students are appointed to submit their reports in front of the class. Other students listen to what is presented by their friends with the purpose conveyed to other students to avoid meaningful mistakes. They are challenged to find answers to their curiosity, because in the presentation other students will give a rebuttal if what is presented by their friends is a finding that is not in accordance with the truth. These findings are also supported by the opinion of Istikomah (2010) which states that in the group investigation learning model, this presentation provokes students to develop an open attitude towards other people's opinions and self-opinion, because information obtained in investigations is presented to other students, students will become more intrigued to be diligent in learning.

Evaluating stage is able to train students to develop an attitude of respect for data. It appears that during learning in the final stages of learning the teacher provides an evaluation test to students to measure how far the material achievements of the earth and the universe are understood by students. When given an evaluation test by the student teacher no one cheated on students working on the questions themselves according to their abilities.

Based on the explanation of the activity of the group investigation learning model above shows that the learning atmosphere feels more effective. In learning students not only learn material theoretically which is often done by memorizing only, but students are involved directly from the planning to the final 
presentation. This learning model has several advantages including, student-centered learning, learning made to create an atmosphere of mutual cooperation and interaction between students in groups regardless of background, able to train students to communicate well in expressing their opinions, and able to foster students' scientific attitudes such as attitude of curiosity, respect for being able to, critical thinking, and an open minded attitude. The findings are supported by research conducted by Ariawan (2016) which states that the application of cooperative learning models of the type of learning investigation group makes students actively construct their own knowledge, able to compile and solve problems through critical, creative, analytical and productive thinking. The involvement of students actively both physically and mentally in experimental activities will have an influence on the formation of a mindset that is based on scientific considerations. If students are accustomed to learning in this way, the scientific attitude will develop better in the future.

Unlike the control class with a conventional learning model characterized by teacher-centered learning, teachers dominate learning activities. In the learning process students tend to be passive and only record, memorize, do assignments, and listen according to the teacher's instructions without trying to find out the concepts learned. This finding is supported by the opinion (Suputra, 2013) which states that learning in the control class is dominated by lecture activities conducted by the teacher. This activity causes students to be less able to apply the concepts learned in everyday life because the initial knowledge possessed by students is not considered as students' potentials and student opinions.

The difference in learning methods between learning with cooperative learning models investigation group type and conventional learning models will certainly have a different impact on students' scientific attitudes. This can be seen from the average score of scientific attitudes of students who are taught by cooperative learning models of type group investigation greater than students who are taught by conventional learning models.

The results of this study are in line with the results of several studies on the application of cooperative learning models in the type of group investigation. The research conducted by Indrani (2017) entitled "Effect of Cooperative Learning Type Group Investigation Model on Science Critical Thinking Ability of Class V Students at SD Gugus 3 Kuta Utara Badung Academic Year 2016/2017". The results of this study show that students 'critical thinking skills of the students who were taught by cooperative learning models of group investigation types were higher than those of students' natural science thinking abilities taught by conventional learning models. So that the cooperative learning model investigation group type should be applied as an alternative to the model that can be used in learning.

Another study was also conducted by Ariawan (2016) which showed that there were significant differences in the science learning outcomes of fourth grade students in Sidet Village. The 2014/2015 school year between students who took part in learning using cooperative learning models investigation groups and students who followed the learning model conventional. It was explained that the increase in science learning outcomes was due to the effective and efficient application of the group investigation learning model to make science learning more meaningful. The research was also supported by the research conducted by Maha (2017) which showed that there were significant differences in science learning outcomes between students who followed the GI type cooperative learning model and those that followed the conventional learning model.

From the results of the research that has been done, there are several advantages that have been obtained after the implementation of the group investigation learning model, namely students become more active in learning and able to develop affective abilities in students such as the development of scientific attitudes in students. This happens because each stage of the investigation group learning model is able to involve students to interact with their groups. Through interaction in groups, the students are most diligent to explore their own knowledge through the activities of discoveries carried out through practical activities or others. In addition, students are able to develop attitudes to accept whoever becomes a member of their group, respond to opinions and cooperate with other friends, students are also more active and more confident in conveying questions and answers with the teacher and friends while learning takes place.

Then it can be synthesized that there are significant differences in students' learning outcomes of science learned by cooperative learning models group investigation with students who are taught with conventional learning models in class V students in Cluster I District of Buleleng 2017/2018 Academic Year.

In addition to the research that has been conducted by several researchers above, this study also shows that the scientific attitude score of students who study science with a group investigation learning model has a high tendency to score. The acquisition of scientific attitude scores of students who followed the group investigation learning model was better than the acquisition of scientific attitude scores of students who followed the conventional learning model. 
Thus, the application of cooperative learning model type group investigation has a positive effect on the scientific attitude of class V Cluster I of Buleleng Subdistrict.

\section{Conclusion}

Based on the results of the research and discussion that has been described, it can be seen that there are differences in scientific attitudes of students between groups of students learned by the investigation group learning model and groups of students who are taught with conventional learning models in class V elementary school in Cluster I Buleleng District 2017/2018 school year. This can be seen from the average score of students' scientific attitudes and the results of the t-test. The average scientific attitude score of the group of students who were taught by group investigation learning model was higher than the average scientific attitude score of the student group taught with conventional learning models (83.71> 68.47). Furthermore, based on the results of the t-test calculation, it is known that tcount $=9.99$ and $t$ table with $\mathrm{dk}=(28+32)-2=58$ at the significance level of $5 \%$ is 2,000 . This means that tcount is greater than $\mathrm{t}$ table ( $\mathrm{t}$ count $>\mathrm{t}$ table), so $\mathrm{HO}$ is rejected and $\mathrm{Ha}$ is accepted. Thus, it can be concluded that the cooperative learning model type group investigation influences the scientific attitude of fifth grade elementary school students in Cluster I Buleleng Subdistrict, 2017/2018 academic year. The application of cooperative learning model type group investigation has a positive effect on improving students' scientific attitudes. For this reason, this study is suggested to teachers. Teachers should be more creative and innovative in choosing learning models so that learning becomes effective and can instill scientific attitudes in students. To the principal in order to be able to support the application of innovative learning models in the classroom one of them is the group investigation learning model. Schools should be able to support the implementation of optimal learning through the provision of adequate learning facilities such as teaching aids and learning media and are able to direct the understanding of teachers to treat students as learning centers. To other researchers For researchers who are interested in conducting further research on cooperative learning models in the type of group investigation in the field of science and other fields of science in order to pay attention to the obstacles experienced in this study as a material consideration for the improvement and refinement of research to be carried out.

\section{References}

Agung, A. A. Gede. 2014. MetodologiPenelitianPendidikan. Malang: Aditya Media Publishing.

Ariawan, K. D, dkk. (2016). Pengaruh Model Pembelajaran Kooperatif Tipe Group Investigation Berbasis Media Lingkungan Terhadap Hasil Belajar Ipa Siswa Kelas Iv Di Desa Sidetapa. Vol. 4, No. 1, (hal. 110). Tersedia pada: https://ejournal.undiksha.ac.id/index.php/JJPGSD/article/view/6609 (diakses tanggal 25 Desember 2017).

Ariawan, K. D., Jampel, I. N., Rati, N. W., Pgsd, J., \& Bk, J. (2016). PENGARUH MODEL PEMBELAJARAN KOOPERATIF TIPE GROUP INVESTIGATION BERBASIS MEDIA LINGKUNGAN TERHADAP HASIL BELAJAR IPA SISWA KELAS IV DI DESA SIDETAPA, 1-10. Retrieved from https://ejournal.undiksha.ac.id/index.php/JJPGSD/article/view/6609

Arya, P., Indrani, M., Ardana, I. K., \& Wiyasa, I. K. N. (2017). PENGARUH MODEL PEMBELAJAARAN KOOPERATIF TIPE GROUP INVESTIGATION TERHADAP KEMAMPUAN BERPIKIR KRITIS IPA SISWA KELAS V Jurusan Pendidikan Guru Sekolah Dasar, FIP Universitas Pendidikan Ganesha Singaraja , Indonesia Pendidikan merupakan salah satu sektor y. Retrieved from https://ejournal.undiksha.ac.id/index.php/JJPGSD/article/view/10873

Bundu, Patta. 2006.PenilaianKeterampilan Proses danSikapIlmiahdalamPembelajaranSainsSekolahDasar. Jakarta:

DepartemenPendidikanNasionalDirektoratJenderalPendidikanTinggiDirektoratKetenagaan.

Candiasa, I Made. 2011. PengujianInstrumenPenelitianDisertaiAplikasi Item danBigsteps. Singaraja: Undiksha Press. 
Darmawati, N. P. A. (2013). Pengaruh Model Pembelajaran Children Learning In Science Berbantuan Metode Talking Stick Terhadap. Vol. $1 . \quad$ Tersedia pada: https://ejournal.undiksha.ac.id/index.php/JJPGSD/article/view/789.

Dibia, I K dan Adiasih, M. M. (2017). Penerapan Pendekatan Starter Eksperimen ( Pse) Untuk Meningkatkan Hasil Belajar Mata Pelajaran IPA. Vol. 1, (hal.72-85). Tersedia pada: https://ejournal.undiksha.ac.id/index.php/IJEE/article/view/11442.

Ditriguna, I Nym. A. K. (2013). Pengaruh Model Pembelajaran Learning Cycle 5e Terhadap Sikap Ilmiah Dan Hasil Belajar Ipa Siswa Kelas V Sd Negeri 5 Pedungan. Vol. 3, No. 1. Tersedia pada: https://ejournal.undiksha.ac.id/index.php/JJPGSD/article/view/1460.

Dewi, Gusti. A. P. A. K. (2017). Pengaruh Model Pembelajaran Group Investigation Bernuansa Outdoor Study Terhadap Penguasaan Kompetensi Pengatahuan Ipa Kelas IV. Vol. 1 (hal. 316-324). Tersedia pada: https://ejournal.undiksha.ac.id/index.php/IJEE/article/view/12963.

Dewi, Pande. Pt. Yustika, dkk. (2017). Pengaruh Model Pembelajaran Group Investigation Berbasis Proyek Terhadap Hasil Belajar Ipa Siswa Kelas Iv. Vol. 1, (hlm. 264-271). Tersedia pada: https://ejournal.undiksha.ac.id/index.php/IJEE/article/view/12957.

Indrani, Putu Arya Mirah dkk. (2017). Pengaruh Model Pembelajaaran Kooperatif Tipe Group Investigation Terhadap Kemampuan Berpikir Kritis Ipa Siswa Kelas V. Tersedia pada: https://ejournal.undiksha.ac.id/index.php/JPGSD/article/view/10873.

Istikomah, H., Hendratto, S., \& Bambang, S. (2010). Penggunaan Model Pembelajaran Group Investigation Untuk Menumbuhkan Sikap Ilmiah Siswa. Jurnal Pendidikan Fisika, 6, 40-43 ISSN: 1693-1246. Tersedia pada: Https://Journal.Unnes.Ac.Id/Nju/Index.Php/JPFI/Article/View/1101.

Koyan, I. W. 2011. AssesmendalamPendidikan.Singaraja: UniversitasPendidikanGanesha.

Koyan, I. W. 2012. StatistikPendidikanTeknikAnalisi Data Kuantitatif.Singaraja: UniversitasPendidikanGanesha.

Kurniasih, Imasdan Berlin Sani.2015. RagamPengembangan Model PembelajaranUntukMeningkatkanProfesionalisme Guru. Jakarta: Kata Pena.

Laila, N., Hariyono, \& Sumarmi. (2016). Motivasi Belajar Siswa Menggunakan Model Pembelajaran Kooperatif Tipe Group Investigation. Jurnal Teori Dan Praksis Pembelajaran IPS. Vol. 1, No. 2, (halm.123-129). Tersedia pada: http://journal.um.ac.id/index.php/jtppips/article/view/8819.

Maha, Luh , Kt. Suarni, N. W. (2017). Pengaruh Model Pembelajaran Group Investigation Dan Motivasi Berprestasi Terhadap Hasil Belajar Ipa Kelas Iv, Volume 6 Nomor 3.

Manuaba, I. N. Bagus, dkk. (2014). Pengaruh Metode Talking Stick Terhadap Hasil Belajar Ipa Siswa Kelas V Sd Negeri 1 Karangasem Tahun Pelajaran 2013 / 2014. Vol. 4, No. 1.

Parinduri, S. H, dkk. (2017). The Effect of Cooperative Learning Model Type Group Investigation for Student Conceptual Knowledge and Science Process Skills. Vol. 7. (hlm.49-54). https://doi.org/10.9790/7388-0704034954.

Purwanti, S dan Manurung S. (2015). Analisis pengaruh model pembelajaran Problem Solving dan Sikap Ilmiah Terhadap Hasil Belajar Fisika. Vol. 4 Tersedia pada: http://jurnal.unimed.ac.id/2012/index.php/jpf/article/view/2569.

Rasana, I DewaPutuRaka.2009. LaporanSabbtical Leave Model-model Pembelajaran.Singaraja: Undiksha.

Sari, N. M., Eurika, N. (2016). Penerapan Model Pembelajaran Group Investigation Untuk Meningkatkan Hasil Belajar Siswa Apllication of Group Investigation Learning. Vol. 1. (hlm. 29-41). Tersedia pada: http://jurnal.unmuhjember.ac.id/index.php/BIOMA/article/view/157. 
Istikomah, H., Hendratto, S., \& Bambang, S. (2010). Penggunaan Model Pembelajaran Group Investigation Untuk Menumbuhkan Sikap Ilmiah Siswa. Jurnal Pendidikan Fisika, 6, 40-43. Retrieved from https://journal.unnes.ac.id/nju/index.php/JPFI/article/view/1101

Luh, N., Candra, P., Arini, N. W., Wibawa, I. C., \& Pgsd, J. (2013). PENGARUH MODEL PEMBELAJARAN HEURISTIK VEE MATA PELAJARAN IPA SISWA KELAS IV, 1(1). Retrieved from https://ejournal.undiksha.ac.id/index.php/JJPGSD/article/view/1365

Maha, Luh , Kt. Suarni, N. W. (2017). PENGARUH MODEL PEMBELAJARAN GROUP INVESTIGATION DAN MOTIVASI BERPRESTASI TERHADAP HASIL BELAJAR IPA KELAS IV, 6(3).

Putu, P., Dewi, Y., Manuaba, I. B. S., \& Suniasih, N. W. (2017). PENGARUH MODEL PEMBELAJARAN GROUP INVESTIGATION BERBASIS PROYEK TERHADAP HASIL BELAJAR IPA SISWA KELAS IV, 1, 264-271. Retrieved from https://ejournal.undiksha.ac.id/index.php/IJEE/article/view/12957

Rosepda, S., \& Turnip, B. M. (2015). Analisis pengaruh model pembelajaran, 4(2). Retrieved from http://jurnal.unimed.ac.id/2012/index.php/jpf/article/view/2569

Suputra, W. (2013). PENGARUH MODEL GI ( GROUP INVESTIGATION ) BERORIENTASI KEARIFAN LOKAL TERHADAP KEMAMPUAN BERPIKIR KRITIS. Retrieved from https://ejournal.undiksha.ac.id/index.php/JJPGSD/article/viewFile/806/679

Sayekti, Ika Candra, dkk. (2012). Pembelajaran IPA Menggunakan Pendektana Inkuiri Terbimbing Melalui Metode Eksperimen dan Demonstrasi Ditinjau dari Kemampuan Analisis dan Sikap Ilmiah Siswa. Vol. 1, No. 2.2 (halm. 142-153). Tersedia pada: http://jurnal.pasca.uns.ac.id/index.php/ink/article/view/130.

Septiari, N. L. Pt Candra, dkk. (2013). Pengaruh Model Pembelajaran Heuristik Vee Mata Pelajaran Ipa Siswa Kelas IV. Vol. 1, No. $1 . \quad$ Tersedia pada: https://ejournal.undiksha.ac.id/index.php/JJPGSD/article/view/1365.

Suartika, I B. Arnyana, G. A. S. (2013). Pengaruh Model pembelajaran Kooperatif Tipe Group Investigation (GI) Terhadap Pemahaman Konsep Biologi Dan keterampilan Berpikir Kreatif Siswa SMA. E-Journal Program Pascasarjana Universitas Pendidikan Ganesha, 3, 12.

Suputra, W. 2013. Pengaruh Model Gi (Group Investigation) Berorientasi Kearifan Lokal Terhadap Kemampuan Berpikir Kritis. Tersedia pada: https://ejournal.undiksha.ac.id/index.php/JPGSD/article/viewFile/806/679 (diakses tanggal 20 Januari 2018). 